\title{
REALIZATION OF INTERPERSONAL MEANING IN U.S PRESIDENT BARACK OBAMA'S SPEECH AT VIETNAM CONVENTION CENTRE: A MOOD SYSTEM ANALYSIS
}

\author{
Nguyen Thu Hanh*, Nguyen Tien Lam \\ Military Science Academy \\ Kim Chung, Hoai Duc, Hanoi, Vietnam \\ Received 3 November 2020 \\ Revised 30 December 2020; Accepted 25 January 2021
}

\begin{abstract}
This study investigated the interpersonal meaning which lies on the diplomatic speech delivered by Barack Obama at Vietnam Convention Centre. The purposes of this study were to describe the construction of the interpersonal meaning of Obama's speech and the contribution of this construction for interpreting his attitudes towards Vietnam. This study used qualitative approach as its main method and clause was chosen as the unit of analysis. The data for this study were analyzed using the MOOD system, including Mood element, Residue, and Mood types. Based on this analysis, it can be concluded that the interpersonal meaning in Obama's speech was mainly realized through Mood types, modal auxiliary, subjects and tense shift. The dominant appearance of declarative clauses, the frequent employment of modals will, can, should and have to, the preference for the first person pronouns $I$ and $w e$ in the speech means that Obama wanted to give information as much as possible to the audience, to shorten the distance between him (as the representative of the United States) and the audience as well as maintaining an equal, reliant relationship between them.
\end{abstract}

Key words: interpersonal meaning, modality auxiliary, Mood system, Residue, Obama's speech

\section{Introduction}

Nowadays, there are many grammatical trends and each of them views language from different perspectives. Among those, Systemic Functional Grammar (SFG) has been attracting many linguists all around the world (M. A. K Halliday, C. Matthiessen, R. Hassan, S. Eggins, G. Thompson, Hoang Van Van, Nguyen Thu Hanh, Nguyen Thanh Nga, etc.). It is particularly helpful for explaining how language is selected and organized in particular ways for particular socio-cultural purposes. Thus, it can help us to understand human language more deeply and comprehensively.

In SFG, Halliday and Matthiessen (2004, 2014) propose that language has three metafunctions: the ideational, the interpersonal and the textual. Many studies related to interpersonal meaning of language have been conducted by researchers all over the world like Feng and Liu (2010), Mafruchatunnisa and Agustein (2016), Tran (2011), and Ye (2010). These studies uncover interpersonal meaning

\footnotetext{
* Corresponding author. Tel.: 84-989150875

Email: nguyenthuhanh09@gmail.com
}

from the perspective of Functional Grammar with the focus on mood, modal auxiliary, personal pronouns, and tense shift in political speeches. The findings show that the addressers make full use of the language to achieve their political purposes in their speeches by using different devices to fulfill interpersonal meaning such as the frequent applications of we and we - you - we pattern helping to create an intimate dialogic style, which can shorten the distance between the addresser and the audience and further persuade the audience to share the same proposal of the addresser.

However, until now, an analysis of U.S President Barack Obama's speech at Vietnam Convention Center from the perspective of interpersonal metafunction has never been investigated by any researcher. Therefore, the current paper primarily aims at examining the social, functional aspect of language in U.S President Barack Obama's speech at Vietnam Convention Center by investigating the realization of interpersonal meaning in this speech. More specifically, the research tries to give an explanation about the phenomenon of the written data with respect to MOOD system used in U.S President Barack Obama's speech 
at Vietnam Convention Center and from this analysis, the study hopes to bring to light his attitudes towards Vietnam.

\section{Halliday's theory on metafunctions and MOOD system}

Within Functional Grammar, the theory on metafunctions was proposed by Michael Halliday (1985, 1994) who later collaborated with Christian Matthiessen (Halliday \& Matthiessen 2004, 2014) and, together, they claim that language has three metafunctions: the ideational, the interpersonal and the textual. Each metafunction is concerned with a meaning, and each meaning "forms part of a different functional configuration, making up a separate stand in the overall meaning of the clause" (p. 83). Of these three metafunctions, interpersonal one plays the role of setting up and maintaining social relations and indicates the roles of the participants in the communication. It deals with the way language expresses the writer's or speaker's reaction towards others and writer's or speaker's attitudes towards a subject. Halliday and Matthiessen (2014, p. 30) assert that "the clause of the grammar is also a proposition, or a proposal, whereby we inform or question, give an order or make an offer, and express our appraisal of and attitude towards whoever we are addressing and what we are talking about. This kind of meaning is more active: if the ideational function of the grammar is 'language as reflection', this is 'language as action'. We call it the interpersonal metafunction". This metafunction is realized through MOOD system.

MOOD, together with modality and polarity, is the major interpersonal system of the clause. It consists of Mood element and Residue. According to Halliday and Matthiessen (2014, p. 140), the Mood element consists of two parts: (1) the Subject, which is a nominal group, and (2) the Finite operator, which is part of a verbal group. In the relation of these functional elements, the Subject approves or disapproves argument whereas the Finite shows primary tense and modality. Because primary tense is time relative to 'now', the internal meaning of a proposition which refers to 'past', 'present' or 'future' time is heavily dependent on the 'primary tense' of the clause. Halliday and Matthiessen (2014, p. 144) views that through modality the speaker takes up a position and signals the status and validity of his own judgments. If the commodity being exchanged is information, the clauses are labeled as proposition and modality expressions are termed as modalization which refers to the validity of proposition in terms of probability and usuality. If the commodity is goods and services, the clauses are defined as proposals and modality expressions are termed as modulation which reflects how confident the speaker can be in the eventual success of the exchange in terms of obligation and inclination.

The Residue consists of functional elements of three kinds: Predicator - a verbal group minus the temporal or modal operator; Complement - an element within the Residue that has the potential of being Subject but is not; and Adjunct - an adverbial group or a prepositional phrase which contributes some additional (but non-essential) information to the clause. There can be only one Predicator, one or two Complements, and an indefinite number of Adjuncts. Here is an example to illustrate MOOD system:

\section{Table 1}

Illustration of MOOD System

\begin{tabular}{ccccc}
\hline Sister Susie & 's & sewing & shirts & for soldiers. \\
\hline Subject & Finite & Predicator & Complement & Adjunct \\
\hline
\end{tabular}

In terms of MOOD types, Halliday and either indicative or imperative in MOOD (see Matthiessen (2014) state that a major clause is Figure 1). 


\section{Figure 1}

The MOOD System Network (Halliday \& Matthiessen, 2014, p. 23)

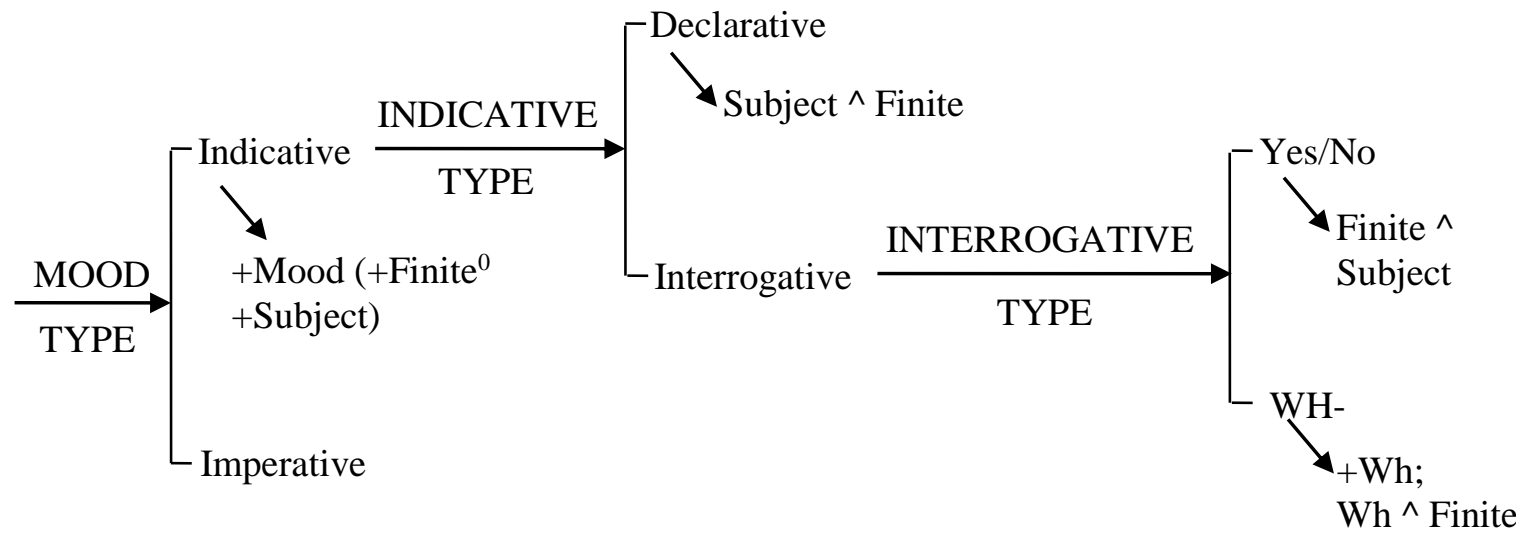

An indicative clause is either declarative or interrogative; if declarative, the Subject comes before the Finite. An interrogative clause is either yes/no type or WH-type; if yes/no type, the Finite comes before the Subject; if WHtype, it has a Wh-element. The imperative has a different system of person from the indicative. Since the imperative is the mood for exchanging goods and services, its Subject is "you" or "me" or "you and me". The features of imperatives could be: Subject only (you), Finite only (do, don't), Finite followed by Subject (don't you) or they may have no Mood element (e.g. look - Predicator only, with no Finite in it).

\section{Methodology}

In this paper, the descriptive method was used as guidance for conducting the research. It was based on the reason that the steps like gathering, analyzing and interpreting the data were included in this method. This study was intended to describe U.S President Barack Obama's speech at Vietnam Convention Center based on SFG, particularly MOOD system proposed by Halliday and Matthiessen $(2004,2014)$ and to find out how the realization of interpersonal meaning of Obama's speech reflects his attitudes towards Vietnam. The method of the study was accomplished through two stages. Firstly, the text was closely read to get a comprehensive understanding. Secondly, the text was analyzed through MOOD system in SFG. The text was firstly approached from a general point of view in that the text was treated as a whole, then it was approached from more specific one - clause by clause, and finally to appraisal tokens in the written text.

The clause has been chosen as the primary unit of analysis in this study as Halliday and Matthiessen (2014, p. 10) claim "the clause is the central processing unit in the lexicogrammar - in the specific sense that it is in the clause that meanings of different kinds are mapped into an integrated grammatical structure". Making the same point, Eggins (1994) states that when the stratum of language to analyze is lexicogrammar, the unit of analysis or description is the clause.

The object of this study was U.S President Barack Obama's speech at Vietnam Convention Center. It was delivered in front of 2,000 attendees on May 24 2016 during U.S President Barack Obama's official visit to Vietnam. To count for authenticity, the data were collected through the following steps:

- Accessing: The researcher browsed into the internet and looked for U.S President Barack Obama's speech at Vietnam Convention Center.

- Finding: The researcher found U.S President Barack Obama's speech at Vietnam Convention Center entitled "Remarks by President Obama in Address to the People of Vietnam".

- Downloading: The transcript of the speech was downloaded from www.whitehouse.gov the official website of the U.S White House.

The data were analyzed manually: the data were sorted and tabulated, and then these elements were analyzed and evaluated to see how they contribute to the findings of the study. 
In more details, the data was analyzed in the following steps:

- Reading: The research team thoroughly read the transcript of U.S President Barack Obama's speech at Vietnam Convention Center in order to get a comprehensive understanding.

- Segmenting the text into clauses: the text was divided into sentences, and then those sentences were segmented into clauses. Let us consider the following example:

(Cl.21) So I come here mindful of the past, mindful of our difficult history,// but focused on the future - the prosperity, security and human dignity // that we can advance together.

In the above example, it can be seen that there are three major clauses within a sentence and they are divided with the double slash.

- Analyzing the clauses through MOOD system: With the aim of demonstrating how MOOD system is analyzed in a clause, the research team analyzed it from clauses in the first paragraph of the text. For example:

(Cl.10a) Last night, I visited the Old Quarter here in Hanoi.

\begin{tabular}{|c|c|c|c|c|c|}
\hline Last night & $I$ & \multicolumn{2}{c|}{ visited } & the Old Quarter & here in Hanoi \\
\hline Adjunct & Subject & Finite & Predicator & Complement & Adjunct \\
\hline \multicolumn{5}{|c|}{ Mood } & Residue \\
\cline { 2 - 5 }
\end{tabular}

It notes that in analyzing clauses, embedded clauses were marked off with double square brackets [[ ]]. Consider the following example:

(Cl.7) We have Vietnamese from across this great country, including so many young people [[who represent the dynamism, and the talent and the hope of Vietnam]].

In this example, the clause within the double square brackets is an embedded clause and functions as the modifier of "so many young people".

- Classifying types of Subjects, Tense, and Modal Auxiliary: Subject, Tense and Modal Auxiliary were identified in each clause and then the results were tabulated.

- Determining Mood types of the clauses: The type of each clause was identified whether it was declarative, interrogative or imperative. After that, the results were tabulated.

\section{Realization of interpersonal meaning in U.S. President Barack Obama's speech through MOOD system}

In order to realize interpersonal meaning of U.S President Barack Obama's speech and to see how this realization reflects Obama's attitudes towards Vietnam in his speech at Vietnam Convention Center, the speech was analyzed through MOOD system including constituents of Mood, of Residue and Mood Types.

\subsection{Constituents of the MOOD}

The Subject in the Mood structure specifies the responsible element in the proposition or proposal. It is that element on which the validity of the information is made to rest (Gerot \& Wignell, 1994, p. 146). Here are some typical Subjects identified in Obama's speech:

(Cl.7) We have Vietnamese from across this great country, including so many young people who represent the dynamism, and the talent and the hope of Vietnam.

(Cl.10) Last night, I visited the Old Quarter here in Hanoi and enjoyed some outstanding Vietnamese food.

(Cl.34) And on the day that Vietnam declared its independence, crowds took to the streets of this city, and Ho Chi Minh evoked the American Declaration of Independence.

(Cl.39) At your war memorial not far from here, and with family altars across this country, you remember some 3 million Vietnamese, soldiers and civilians, on both sides, who lost their lives.

(Cl.115) And the United States is ready to assist Vietnam as it works to fully implement its commitments.

In the above examples, I, we, you, Vietnam and the United States are the subjects of clauses found in Obama's speech. The frequency of Subjects identified in Obama's speech is shown in Table 2. 
Table 2

Frequency of Subjects Identified in Obama's Speech

\begin{tabular}{cccccccc}
\hline Subjects & $I$ & We & You & Vietnam & The United States & Others & Total \\
\hline Times & 68 & 63 & 28 & 18 & 12 & 280 & 469 \\
\hline Frequency (\%) & 14.49 & 13.43 & 5.97 & 3.83 & 2.55 & 59.73 & 100 \\
\hline
\end{tabular}

Among these Subjects, I, we and you are personal pronouns. They have the interpersonal function in discourse by establishing a certain relationship between the addresser and the audience in a speech. The choice of the first personal pronouns $I$ and we and the second personal pronoun you may provide different meanings in the interpretation of the text. As evident in many SFG researches, e.g. Thompson (2004) and Mulderrig (2011), the first person singular pronoun $I$ is always exclusive, while the first person plural we is usually inclusive. First person singular pronoun $I$ is exclusive because it refers to the addressers themselves leaving out the audience, while first person plural we is usually inclusive because it includes both the addresser and the audience in the propositions being advanced. Second personal pronoun you is mostly exclusive because it directly refers to the person(s) being addressed.

Through data analysis, a total of 469 Subjects are used in Obama's speech. The first person singular pronoun $I$ is used 68 times, accounting for $14.49 \%$. The pronoun we is discovered 63 times (13.43\%). The second person pronoun you turns up 28 times with a percentage of $5.97 \%$ throughout the speech. The Subjects Vietnam and the United States respectively appear 18 times (3.83\%) and 12 times (2.55\%). And other Subjects appear 280 times $(59.73 \%)$ in Obama's speech. However, they will not be discussed in this research because they are not central in the speech interaction.

According to the result, it can be seen that $I$ is the most frequent Subject found in Obama's speech. I here refers to the speaker of the speech that is U.S President Barack Obama. It means that Obama himself takes responsibility for the speech. Moreover, the research team found that the Subject I mainly falls into the following categories in the speech: to express Obama's gratitude to certain people, to describe the specific deeds and to present his personal beliefs and comments. For example:
(Cl.5) To the government and the people of Vietnam, $\wedge I$ thank you for this very warm welcome and the hospitality that you have shown to me on this visit (expressing his gratitude to the government and the people of Vietnam).

(Cl.13) But I have to say, the busy streets of this city, I've never seen so many motorbikes in my life (presenting his personal comment).

(Cl.82) And I believe our experience holds lessons for the world (presenting his personal belief).

(Cl.130) With the announcement I made yesterday to fully lift the ban on defense sales, Vietnam will have greater access to the military equipment you need to ensure your security (describing a specific deed).

In SFG, the pronoun we is usually inclusive but it can also be exclusive. The inclusive stands for "I and you (the person(s) spoken to)", which holds emotional effectiveness to shorten the distance between the speaker and the audience. It can make them sense that they share a common objective. The exclusive is equal to "I and others", not "I and you (the person(s) spoken to)". By statistics, in Obama's speech, pronoun we turns up for 63 times, of which 37 are inclusive ones and 26 are exclusive ones. They can be seen partly in the following examples:

(Cl.21) So I come here mindful of the past, mindful of our difficult history, but focused on the future - the prosperity, security and human dignity that we can advance together.

(Cl.63) Even as we continue to assist Vietnamese with disabilities, including children, we are also continuing to help remove Agent Orange - dioxin - so that Vietnam can reclaim more of your land.

In the above examples, the first person pronoun we mentions "the United States and Vietnam", making the audience experience a feeling that the United States and Vietnam are in the same boat and there is no distance between two nations. Obama, as the representative of the United States, positions Vietnam as a friend and a partner of the United 
States so that two nations share common objectives and can work together. Moreover, giving the Subject we means that Obama wants to share responsibility between the United States and Vietnam. By this way, Obama successfully shortens the distance between him (as the representative of the United States) and the audience as well as maintains an equal and reliant relationship between them, thus greatly helps to persuade the audience to share his same proposal. The second person plural pronoun we refers to "Obama and all American people". It gives an impression that there is a unity between the U.S government and its citizens in giving response to other countries in the world and policies and actions of the U.S government are supported by all American people.

In his speech, Obama also made you - the audience as the Subject of the clauses in his speech in order to attract their attention and also to make them get involved in the speech. It is also the way Obama shows his respect to the audience. There are 18 items of Vietnam as the Subject of the clauses in the speech. This is understandable since what Obama talks is mostly about U.S relations with Vietnam but not any other countries. There are 12 items expressing the United States or America as the Subject in order to show the world that Obama speaks as the representative of the United States. What he is sharing in his speech represents what the United States says to the world.

\section{- Primary Tense}

Tense is the time of a clause. Halliday and Matthiessen $(2004,2014)$ point out that primary tense means past, present or future at the moment of speaking; it is the time relative to "now". Here are some examples about tenses found in Obama's speech:

(Cl.22) I also come here with a deep respect for Vietnam's ancient heritage. (Present tense)

(Cl.30) More than 200 years ago, when our Founding Father, Thomas Jefferson, sought rice for his farm, he looked to the rice of Vietnam, which he said had "the reputation of being whitest to the eye, best flavored to the taste, and most productive." (Past tense)

(Cl.163) And ultimately, the future of Vietnam will be decided by the people of Vietnam. (Future tense)

Table 3 shows the frequency of the primary tenses found in the speech. On the basis of the statistics of tenses, we can see that present tense is the most frequent one used in the speech with a percentage of $77.61 \%$. Past tense ranks second with a percentage of $15.99 \%$ and is followed by future tense with a percentage of $6.4 \%$. Biber et al. (1999, p. 457) state that "the preference for present tense verbs is particularly strong in conversation, the reliance on present tense reflects speakers' general focus on the immediate context". Thus, the finding indicates that Obama wants to focus on the real condition at the moment of speaking. He focuses on presenting the relations between the United States and Vietnam ranging from different areas like prosperity, security and human dignity at present.

Table 3

Frequency of Primary Tenses Found in Obama's Speech

\begin{tabular}{ccccc}
\hline Tense & Past & Present & Future & Total \\
\hline Times & 75 & 364 & 30 & 469 \\
\hline $\begin{array}{c}\text { Frequency } \\
(\%)\end{array}$ & 15.99 & 77.61 & 6.40 & 100 \\
\hline
\end{tabular}

- Modality

There are different ways to realize modality, including modal auxiliary, adverbs, intonation and mental-process verbs. However, this study will focus on modal auxiliary. According to Halliday and Matthiessen (2004, 2014), three basic values of modal commitment are high, median and low on the scale. And different scales of modal commitment lead to different meanings. Table 4 below presents the frequency of modal auxiliary used in Obama's speech.

\section{Table 4}

Frequency of Modal Auxiliary in Obama's Speech

\begin{tabular}{ccccccc}
\hline Modal auxiliary & Can & Will & Should & Have to & Others & Total \\
\hline Times & 26 & 29 & 06 & 06 & 10 & 77 \\
\hline Frequency $(\%)$ & 33.76 & 37.66 & 7.80 & 7.80 & 12.98 & 100 \\
\hline
\end{tabular}


From the above table, we can find that will is used most frequently, accounting for 29 times $(37.66 \%)$. It is mainly employed to provide information about what will happen in the future, for example:

(Cl.101) As I announced yesterday, the Peace Corps will come to Vietnam for the first time, with a focus on teaching English.

(Cl.105) The new Fulbright University Vietnam will open in Ho Chi Minh City - this nation's first independent, non-profit university - where there will be full academic freedom and scholarships for those in need.

(Cl.128) We will continue to offer training and equipment to your Coast Guard to enhance Vietnam's maritime capabilities.

(Cl.129) We will partner to deliver humanitarian aid in times of disaster.

Through using the modal auxiliary will, U.S President Obama reveals his views towards Vietnam in the future and the effect of those views is strengthened by his power and authority.

Besides, will is used to illustrate Obama's strong determination. Consider the following:

(Cl.142) But we will stand with partners in upholding core principles, like freedom of navigation and overflight...

(Cl.143) As we go forward, the United States will continue to fly, sail and operate wherever international law allows, and we will support the right of all countries to do the same.

From the above examples, it can be understood that Obama shows the determination of the United States in upholding the international law. But actually, he also wants to show the power of the United States to the world and confirm that America is the global superpower.

The modal auxiliary can turns up 26 times $(33.76 \%)$ in the speech, ranking the second position in the frequency of modal auxiliary in Obama's speech. It is one of low modals. Hickel (2009) observes that these modals indicate lack of speaker's confidence in the truth of the propositions which are being advanced. However, Obama still uses this modal in his speech with a high frequency. There are some considerations for this choice. On one hand, can is seen as the lowest degree of pressure, opening the possibility for the other people to do the action but leaving the decision to them; with regard to this, Obama uses can to weaken his authority, shorten the distance between him and the audience and not to force them to follow his instruction. On the other hand, according to Kondowe (2014), can often serves to mark personal belief, possibility, likelihood and politeness in discourse. Thus, the use of can not only shows Obama's politeness but also expresses his hope, possibility and likelihood. Obama tries to inspire and elicit hope from the audience, for example:

(Cl.21) So I come here mindful of the past, mindful of our difficult history, but focused on the future - the prosperity, security and human dignity that we can advance together.

(Cl.92) And with the time I have left, I want to share with you the vision that I believe can guide us in the decades ahead.

(Cl.184) Finally, our partnership I think can meet global challenges that no nation can solve by itself.

In his speech, Obama also used the modal auxiliary should with the occurrence of 6 times $(7.8 \%)$. This modality is realized as the "obligation" modality and it is involved as median category in expressing the speaker's judgment or attitude about something:

(Cl.133) Nations are sovereign, and no matter how large or small a nation may be, its sovereignty should be respected, and its territory should not be violated.

(Cl.134) Big nations should not bully smaller ones.

(Cl.135) Disputes should be resolved peacefully.

Here, by using the modal should, it is clear that Obama wants to express his attitude about the sovereign of a country.

As seen in Table 4, the modal have to occurs 06 times (7.8\%) in the speech. As a high modal, have to carries out the degree of obligation on the person to carry out a command. Thus, most political speeches adopt have to to convey the speaker's strong determination and call on the audience to be determined to take action to achieve their common objectives. It is shown in the following examples:

(Cl.125) So we now have to get it done - for the sake of our economic prosperity and our national security.

(Cl.182) But there are these basic principles that I think we all have to try to work on and improve. 
(Cl.186) Natural wonders like Ha Long Bay and Son Doong Cave have to be preserved for our children and our grandchildren.

From the above analysis, we can conclude that the most dominant modal used in the speech is will and it is followed by the modal can, should, and have to. Obama uses the modal will with the highest frequency in order to reveal his views towards Vietnam in the future and show his strong determination in ensuring the implementation of the international law. He also tends to shorten the distance between him and the audience in order to establish a good relationship between them and give hope and anticipate the future by using modal can rather than enforcing on the audience, through which, a good relationship is well established.

\subsection{Constituents of RESIDUE}

According to White (2001, p. 89), the Mood element plays a central role in the arguability of a clause as it is the element which will be passed back and forth in any debate. Residue component is another component of the clause that is somehow less essential to the arguability of a clause than the Mood element, but Residue structure also contains a number of functional elements: Predicator, Complements, and different kinds of Adjuncts. Therefore, the constituents of Residue will be discussed in this study.

\subsubsection{Predicators}

Predicator is a verb part of the clause which shows what is happening. Here are some examples of Predicator identified in the speech:

(Cl.24) At this bend in the river, Hanoi has endured for more than a thousand years.

(Cl.28) But like bamboo, the unbroken spirit of the Vietnamese people was captured by Ly Thuong Kiet "the Southern emperor rules the Southern land. Our destiny is writ in Heaven's Book."

(Cl.43) More recently, over the past two decades, Vietnam has achieved enormous progress, and today the world can see the strides that you have made.

Through the analysis of Predicator, it can be found that a fusion of Finite with Predicator appears in many clauses of the speech, for example:

(Cl.10) Last night, I visited the Old Quarter here in Hanoi and enjoyed some outstanding Vietnamese food.
(Cl.25) The world came to treasure Vietnamese silks and paintings, and a great Temple of Literature stands as a testament to your pursuit of knowledge.

(Cl.47) We see Vietnam's progress in the skyscrapers and high-rises of Hanoi and Ho Chi Minh City, and new shopping malls and urban centers.

As its function, Predicator tells us about what is (are) one(s)/something(s) doing towards one(s)/something(s). It indicates what activity that occurs in a situation.

\subsubsection{Complements}

A Complement is an element within the Residue that has the potential of being Subject but is not. A complement is typically realized by a nominal group. It answers the question "is/had what", "to whom", "did to whom" and "did to what". Complement is partly identified in the following examples:

(Cl.81) But now we can say something that was once unimaginable: Today, Vietnam and the United States are partners.

(Cl.113) Here in Vietnam, TPP will let you sell more of your products to the world and it will attract new investment.

(Cl.115) And the United States is ready to assist Vietnam as it works to fully implement its commitments.

\subsubsection{Adjuncts}

An Adjunct is an element that has not got the potential of being Subject. It is typically realized by an adverbial group or a prepositional phrase. And Adjunct itself is divided into four types: Circumstantial Adjunct, mood Adjunct, comment Adjunct and conjunctive Adjunct. Thus, in this study, Adjunct component will be identified according to these types.

\section{- Circumstantial Adjunct}

As Halliday and Matthiessen (2014) state, circumstantial Adjunct may refer to time (when), place (where), cause (why), matter (about what), accompaniment (with whom), beneficiary (to whom), agent (by whom). Some examples of circumstantial Adjunct are shown as follows:

(Cl.18) So my first exposure to Vietnam and the Vietnamese people came when I was growing up in Hawaii, with its proud Vietnamese American community there. 
(Cl.57) That's what you have been able to achieve in a very short time.

(Cl.64) We're proud of our work together in Danang, and we look forward to supporting your efforts in Bien Hoa.

(Cl.65) Let's also not forget that the reconciliation between our countries was led by our veterans who once faced each other in battle.

In the above examples, circumstantial Adjunct in a very short time answers the question "when", while circumstantial Adjuncts in Danang, in Bien Hoa answer the question "where". Circumstantial Adjunct with its proud Vietnamese American community answers the question "with whom", while circumstantial Adjunct by our veterans answers the question "by whom".

\section{- Mood Adjunct}

According to Halliday and Matthiessen (2004, 2014), mood Adjuncts relate specifically to the meaning of the finite verbal operator, expressing "probability", "usuality", "obligation" and "inclination of time". This kind of Adjunct is identified in the following examples:

(Cl.13) But I have to say, the busy streets of this city, I've never seen so many motorbikes in my life. (Usuality)

(Cl.14) So I haven't had to try to cross the street so far, but maybe when I come back and visit you can tell me how. (Probability)

(Cl.17) When the last U.S. forces left Vietnam, I was just 13 years old. (Time)

(Cl.42) Just as we learned in America that, even if we disagree about a war, we must always honor those who serve and welcome them home with the respect they deserve. (Usuality)

(Cl.65) Let's also not forget that the reconciliation between our countries was led by our veterans who once faced each other in battle. (Time)

- Comment Adjunct

Comment Adjuncts are considered interpersonal elements in the clause, since they add an expression of attitude and evaluation. They are realized by adverbs. Unfortunately, there is only a comment Adjunct found throughout Obama's speech. That is in sentence (Cl.157) So really, this is an issue about all of us, each country, trying to consistently apply these principles, making sure that we - those of us in government - are being true to these ideals. "Really" here is to show the Assertion.

- Conjunctive Adjunct

Conjunctive Adjuncts are expressed by conjunctions, functions to provide linking relations between one clause and another. Conjunctive Adjuncts include items such as "for instance", "anyway", "moreover", "meanwhile", "therefore", and "nevertheless". The examples below will partly show conjunctive Adjuncts identified in the speech:

(Cl.16) But I am the first, like so many of you, who came of age after the war between our countries.

(Cl.18) So my first exposure to Vietnam and the Vietnamese people came when I was growing up in Hawaii, with its proud Vietnamese American community there.

(Cl.34) And on the day that Vietnam declared its independence, crowds took to the streets of this city, and Ho Chi Minh evoked the American Declaration of Independence.

(Cl.70) Because our veterans showed us the way, because warriors had the courage to pursue peace, our peoples are now closer than ever before.

(Cl.176) Then countries can better address challenges that government sometimes cannot solve by itself.

\subsection{MOOD types analysis}

Halliday and Matthiessen (2004, 2014) observe that most of the clauses in English are construed around declaratives, interrogatives and imperatives. The choice of Mood depends on the role the speaker selects in the speech situation and what role he/she assigns to the addressee. In English, the Mood consists of Subject and Finite. The ordering of Subject and Finite in the clause plays an indispensable role in signaling speech roles and it indicates whether the clause is declarative (Subject $\wedge^{\wedge}$ Finite), interrogative $\left(\mathrm{WH}^{\wedge}\right.$ Finite or Finite`Subject) or imperative (Subject "let's" or Finite^Subject). Declarative mood typically gives out information, interrogative expresses a question-typically asking for information, and imperative expresses a directive (Sustein, 1992).

Statistically, out of 469 clauses identified in the speech, 465 are declarative, which constitute $99.14 \%$. The remaining four clauses are imperative $(0.86 \%)$, while no interrogative clause has been found in the analysis (see Table 5). 
Table 5

Frequency of Mood Types

\begin{tabular}{ccccc}
\hline Mood Types & Declarative & Interrogative & Imperative & Total \\
\hline Times & 465 & 00 & 04 & 469 \\
\hline Percentage (\%) & 99.14 & 0 & 0.86 & 100 \\
\hline
\end{tabular}

This result is in tandem with Feng and Liu's (2010) and Ye's (2010) assertion that declarative clauses generally dominate in political speeches, followed by imperatives, while interrogatives usually come last. The purpose of a speech is to express the addresser's viewpoint on things in the world, to elicit or change the audience's attitudes and to arouse the audience's passion to share the same proposal of the addresser. Particularly in a political speech, it is vital for the addresser to give information. Through the speech, the addresser hopes to offer certain messages to the audience showing his political attitude and assumption. Therefore, declarative clauses generally dominate in a political speech, imperative clauses come next to them, and interrogative clauses are the last choices for the reason that they may make a speech less solemn, less convincing and persuasive. With these regards, the dominant appearance of 465 declarative clauses in Obama's speech is successful in that they are functioned as statements to give information as much as possible to the audience.

On the use of imperative clauses, there are four imperative clauses found in Obama's speech. Among those, one clause is cited from the Tale of Kieu by Obama and then will fall outside of the analysis. Halliday and Matthiessen (2004, 2014) state that imperative clauses convey two types of messages: one is to command others to do something, while the other is to offer/suggest the audience to do something or achieve something together. Imperative clauses found in Obama's speech clearly fall under the category of offering/suggesting the audience:

(Cl.65) Let's also not forget that the reconciliation between our countries was led by our veterans who once faced each other in battle.

(Cl.93) First, let's work together to create real opportunity and prosperity for all of our people.
(Cl.165) But as a friend of Vietnam, allow me to share my view - why I believe nations are more successful when universal rights are upheld.

By using these clauses, Obama successfully bridges the gap between him and the audience. Furthermore, such clauses seem to be appropriate for the context of a diplomatic speech. In his speech, Obama did not use interrogative clauses because they may make a speech less solemn, less convincing and persuasive.

\section{Conclusion}

This research applied SFG proposed by Halliday and Matthiessen (2004, 2014) to analyze U.S President Barack Obama's speech at Vietnam Convention Center. The research served as a sample to demonstrate how interpersonal meaning is generally realized in a political speech. From the perspective of the interpersonal metafunction, by analyzing MOOD system in the clauses of Obama's speech, the research team found that the interpersonal meaning in Obama's speech was mainly realized through Mood types, modal auxiliary, subjects and tense shift. In terms of Mood types, declarative clauses dominated Barack Obama's speech, imperative clauses were in the second position, while no interrogative clause was found in the speech. The dominant appearance of declarative clauses in the speech means that Obama wanted to give as much information as possible to the audience. In terms of modal auxiliary, the modals will, can, should and have to turned up frequently to carry on the modality in the speech. By using the modal will with the highest frequency, the views of the United States towards Vietnam in the future were revealed. Meanwhile, by using the modal can in his speech, Obama tended to shorten the distance between him and the audience in order to establish a good relationship between them, 
give hope and anticipate the future rather than enforcing on the audience. In terms of Subjects, the first person pronouns $I$ and we turned up mostly in the speech; the second person pronoun you came next. The pronoun we was both inclusive and exclusive. By using the inclusive one, Obama successfully shortened the distance between him (as the representative of the United States) and the audience and maintained an equal, reliant relationship between them, thus greatly helped to persuade the audience to share his same proposal. And by using the exclusive one, it gave an impression that there was a unity between the U.S government and its people in giving response to other countries in the world. In terms of tense shift, the findings pointed out that the present tense was the most frequent one used in the speech. It means that Obama wanted to focus on the real condition at the moment of speaking.

The research results were in agreement with the previous studies on interpersonal meaning in political speech (Mafruchatunnisa \& Agustein, 2016; Tran, 2011; Ye, 2010) in which they claim that the use of first person $I$ is to express the speaker's will and build his authority while we is used to make sense of intimacy with the audience as well as follow a common objective; in modality, the speaker utilizes tactfully modal verbs of median and low to shorten the distance between him and people so as to successfully establish a sound relation; in mood, the speaker takes the advantage of employing indicative mood to express their propositions to gain support. The tense can be another factor that signalizes political speech because it refers to present, past and future events as well as activities that demonstrate political objectives and at the same time display the world wide situations that extend from political, cultural, and economical fields at present.

\section{References}

Biber, D., Johansson, S., Leech, G., Conrad, S., \& Finegan, E. (1999). Longman grammar of spoken and written English. Pearson Education Limited.

Eggins, S. (1994). An introduction to systemic functional grammar. Pinter.

Feng, H., \& Liu, Y. (2010). Analysis of interpersonal meaning in public speeches - A case study of Obama's Speech. Journal of Language Teaching and Research, 1(6), 825-829.

Gerot, L., \& Wignell, P. (1994). Making sense of functional grammar. Gerd Stabler.

Halliday, M. A. K. (1985). An introduction to functional grammar. Edward Arnold.

Halliday, M. A. K. (1994). An introduction to functional grammar (2nd ed.). Edward Arnold.

Halliday, M. A. K., \& Matthiessen, C. (2004). An introduction to functional grammar (3rd ed.). Hodder Arnold.

Halliday, M. A. K., \& Matthiessen, C. (2014). Halliday's introduction to functional grammar (4th ed.). Routledge.

Hinkel, E. (2009). The effects of essay topics on modal verb uses in L1 and L2 academic writing. Journal of Pragmatics, 41(4), 667-683. https://doi.org/10.1016/j.pragma.2008.09.029

Hoang, V. V. (2018). "Bánh trôi nước" and three English versions of translation: A systemic functional comparison. VNU Journal of Foreign Studies, 34(4), 1-35. https://doi.org/10.25073/2525-2445/vnufs.4279

Kondowe, W. (2014). Hedging and boosting as interactional metadiscourse in literature doctoral dissertation. International Journal of Language Learning and Applied Linguistics World, 5(3), 214-221.

Mafruchatunnisa, I., \& Agustein, H. I. R. (2016). Interpersonal meanings in Michelle Obama's speech at memorial service for Dr. Maya Angelou. Journal of English Language Teaching, 5(1), 1-8.

Mulderrig, J. (2011). Manufacturing consent: A corpus-based critical discourse analysis of new labour's educational governance. Educational Philosophy and Theory, 43(6). https://doi.org/10.1111/j.1469-5812.2010.00723.x

Nguyen, T. H. (2018). M. A. K. Halliday's systemic functional grammar approach to literary text analysis: Theory and application. Journal of Military Foreign Language Studies, 16, 3-15.

Nguyen, T. N. (2017). Doctor-patient power relation: A systemic functional analysis of a doctor-patient consultation. VNU Journal of Foreign Studies, 33(3), 24-43. https://doi.org/10.25073/2525-2445/vnufs.4153

Seidel, G. (1985). Political discourse analysis. Academic Press.

Sunstein, E. (1992). Free speech now.http://chicagounbound.uchicago.edu/cgi/viewcont ent.cgi? article $=4754 \&$ context $=$ uclrev

Thompson, G. (2004). Introducing functional grammar. Foreign Language Teaching and Research Press.

Tran, T. P. N. (2011). The structure and meaning of President Nguyen Minh Triet's speech addressed on the occasion of the $1000^{\text {th }}$ anniversary of the foundation of Thang Long - Hanoi: A Systemic Functional Analysis [Master's thesis, University of Languages and International studies. Vietnam National University, Hanoi].

White, P. R. R. (2001). Functional grammar. Center for English Language Studies.

Ye, R. (2010). The interpersonal metafunction analysis of Barack Obama's victory speech. English Language Teaching, 3(2), 146-151. 


\title{
NGHĨA LIÊN NHÂN THỂ HIỆN TRONG BÀI PHÁT BIỂU CỦA TỔNG THỐNG HOA KỲ BARACK OBAMA TẠI TRUNG TÂM HỘI NGHỊ QUỐC GIA VIẸTT NAM: PHÂN TÍCH HỆ THỐNG THỨC
}

\author{
Nguyễn Thu Hạnh, Nguyễn Tiến Lâm \\ Học viện Khoa học Quân sụ \\ Kim Chung, Hoài Đức, Hà Nội, Việt Nam
}

\begin{abstract}
Tóm tắt: Bài báo này tìm hiểu nghĩa liên nhân thể hiện trong bài phát biểu của Tổng thống Hoa Kỳ Barack Obama tại Trung tâm Hội nghị Quốc gia Việt Nam. Mục đích của nghiên cứu này là mô tả việc thiết lập nghĩa liên nhân trong bài phát biểu của Barack Obama và qua đó giải thích thái độ của ông đối với Việt Nam. Nghiên cứu sử dụng cách tiếp cận định tính làm phương pháp chính và Cú được chọn làm đơn vị nghiên cứu. Dữ liệu cho nghiên cứu được phân tích bằng hệ thống THỨC (MOOD), bao gồm yếu tố Thức, Phần Dư và các mẫu Thức khác nhau. Kết quả nghiên cứu chỉ ra rằng nghĩa liên nhân thể hiện trong bài phát biểu của Obama chủ yếu được hiện thực hóa thông qua các loại Thức, Bổ ngữ tình thái, Chủ ngữ và sự biến đổi của Thì. Sự xuất hiện chủ đạo của các Cú tuyên ngôn, việc sử dụng thường xuyên Bổ ngữ tình thái "sẽ", "có thể", "nên" và "phải làm", sự ưu tiên cho các đại từ ngôi thứ nhất "tôi" và "chúng ta" trong bài phát biểu có nghĩa là Obama muốn cung cấp thông tin càng nhiều càng tốt cho khán giả Việt Nam, để rút ngắn khoảng cách giữa Tổng thống (với tư cách là đại diện của Hoa Kỳ) và khán giả (Việt Nam); từ đó, duy trì mối quan hệ bình đẳng và tương trợ lẫn nhau.

Tù khóa: nghĩa liên nhân, hệ thống Thức, phần Dư, bổ ngữ tình thái, bài phát biểu của Tổng thống Hoa Kỳ Barack Obama
\end{abstract}

